\title{
Application of BASNEF model in students training regarding cutaneous leishmaniasis prevention behaviors: a school-based quasi experimental study
}

Gholamreza Alizadeh ${ }^{1}$, Hossein Shahnazi ${ }^{2^{*}}$ and Akbar Hassanzadeh ${ }^{3}$

\begin{abstract}
Background: Cutaneous leishmaniasis (CL) is endemic in 98 countries, and 350 million people are at risk of the disease worldwide. In endemic areas, conducting educational interventions is necessary to change preventive behaviors of $\mathrm{CL}$. This study aimed to investigate the effect of an educational intervention based on the BASNEF model on CL preventive behavior in students.

Methods: The present quasi-experimental study examined 80 students living in endemic areas of leishmaniasis in Isfahan province, Iran based on the BASNEF model. The required data were collected twice before and two months after the educational intervention based on a questionnaire whose validity and reliability had been already proven in other studies. The intervention was performed in three educational sessions for the students in the intervention group and 1 educational session for teachers and parents. Data were analyzed by SPSS (VER26) using the chi-square test, independent t-test, analysis of covariance (ANCOVA), and Paired t-test.
\end{abstract}

Results: After intervention, the mean scores of Knowledge $(P<0.001)$, attitude $(P=0.02)$, subjective norms $(P=0.04)$, behavioral intention $(P<0.001)$, and behavior $(P=0.02)$ indicated significant differences between the intervention and control groups, but an increase in mean scores of enabling factors was not significant $(P=0.93)$.

Conclusions: Providing students with the educational intervention based on the BASNEF model improve their ability to the extent that they transmit these educations to their family members, which would be effective in preventing and controlling $\mathrm{CL}$ in leishmaniasis-prone areas.

Trial registration: Name: Iranian Registry of Clinical Trials. Registration number: IRCT20201024049131N1. Registration date: 2020-11-20. Registration timing: prospective.

Keywords: Education, Student, Cutaneous leishmaniasis (CL), Prevention

*Correspondence: h_shahnazi@yahoo.com

${ }^{2}$ Department of Health Education and Health Promotion, School

of Health, Isfahan University of Medical Sciences, Isfahan, Iran

Full list of author information is available at the end of the article

\begin{abstract}
Background
Cutaneous Leishmaniasis (CL) is a skin infection that is still a major global health problem, especially in tropical and subtropical countries. CL, which is considered a neglected disease, is becoming more prevalent worldwide [1]. The disease is endemic in more than 98 countries [2], and 12 million people are infected with the disease worldwide, 350 million people are at risk [3-7], and every
\end{abstract}

(c) The Author(s) 2021. Open Access This article is licensed under a Creative Commons Attribution 4.0 International License, which permits use, sharing, adaptation, distribution and reproduction in any medium or format, as long as you give appropriate credit to the original author(s) and the source, provide a link to the Creative Commons licence, and indicate if changes were made. The images or other third party material in this article are included in the article's Creative Commons licence, unless indicated otherwise in a credit line to the material. If material is not included in the article's Creative Commons licence and your intended use is not permitted by statutory regulation or exceeds the permitted use, you will need to obtain permission directly from the copyright holder. To view a copy of this licence, visit http:/creativecommons.org/licenses/by/4.0/ The Creative Commons Public Domain Dedication waiver (http://creativecommons.org/publicdomain/zero/1.0/) applies to the data made available in this article, unless otherwise stated in a credit line to the data. 
year, 1.5 million new cases of CL $[5,8]$ and 20,000 to 40,000 deaths due to this disease occur. [9, 10].

Iran is among the first ten countries in the world based on the number of cases [11]. According to WHO's report in 2017, more than 95\% of new cases of CL occurred in Afghanistan, Algeria, Brazil, Colombia, Iran, Iraq, and Syria. [6, 12].

In Iran, CL is an important disease that is endemic in 18 provinces [13].In this country, more than 22,000 cases of leishmaniasis are being annually reported $80 \%$ of which are zoonotic CL [14]; however, the true number of infected cases is always 4 to 5 times more than the reported and recorded cases because of fear of treatment, and spontaneous improvement in patients, [15].

Comparison of statistics of CL in Iranian provinces indicates that it has the highest prevalence in Isfahan, Fars, and Khorasan provinces [16].For example, Jarghouyeh located in the east of Isfahan is among this province regions in which CL is highly prevalent [17].

This disease can cause many problems for patients, including psychological consequences due to prolonged wound period, the development of undesirable scars on the face, the possibility of secondary infections, the high cost of treatment for the society, the long treatment period, and side effects of treatment with existing drugs [18].

Researchers' failure to develop vaccines for CL and its high prevalence have made health education the top priority of WHO [19].

Numerous studies have also emphasized the importance of health education and public participation in the prevention of CL $[2,20]$. Many researchers have suggested other disease control and prevention programs such as vaccine and drug production, environmental improvement, the extermination of mice, and poison spraying along with health education programs [7].

A major contributing factor to the development of this disease is that most people living in endemic areas don't have enough knowledge about the way in which the disease transmission is prevented. Various studies have found that the public's knowledge about CL is low $[21,22]$.This is a serious alarm because the necessary and correct information is the first and the most fundamental step towards any proper behavior [22].

The results of some studies suggest that instead of authentic resources, people obtain their information from family members, neighbors, and friends who are likely to convey incomplete information and misconceptions to people in society. $[3,23]$.

Attitude and beliefs of people living in endemic regions of $\mathrm{CL}$ need to be corrected or changed. For example, some people wrongly believe that mosquitoes transmitting CL are only present in regions and houses in which dogs and sheep are kept, suitable emollient creams and perfumes can prevent $C L$, and luck and God's wrath play roles in developing CL, etc. [24].

A very effective factor, which helps students living in endemic areas of leishmaniasis pursue CL preventive behaviors, is how much family, friends, classmates, health workers, principals, teachers, and educators take care to perform such behaviors. Family, friends, classmates, and teachers can play a major role in the process of behavior change in students.

A barrier to CL prevention behaviors is that even if people are encouraged to perform the behavior by education, some environmental limitations, such as lack of preventive tools, including proper netting and mosquito nets, insect repellent pen, etc. can prevent them from adopting appropriate behavior. [25].

Young groups and 10 to 15 -year-old students are the most vulnerable groups to $\mathrm{CL}$ in the endemic areas. [26] In a study in Morocco, the children's face lesions were more than adults' [27].

Given that students are the most vulnerable group to this disease and the most accessible group who can, by education, improve knowledge, attitude, and ultimately health behaviors of families, they were selected as the target group of the current study.

The selection of a model or theory is the most important measure taken in educational planning. A model or theory should be based on circumstances, problem, and alignment, and the quality of model/theory to be efficient and convergent with the purpose of the education program [28].

Since that the above-mentioned factors relating to CL preventive behaviors include:attitude, subjective norm, enabling factors, and behavioral intention, the researchers came to the conclusion that a suitable educational intervention can be designed and implemented to teach students to adopt CL preventive behaviors using the BASNEF model. (Fig. 1) [23].

Therefore, the present study aimed to investigate the effect of educational intervention based on the BASNEF model on CL prevention behaviors in male first-grade high school students in the east Isfahan.

\section{Methods}

\section{Study design and sampling}

The present quasi-experimental study examined 84 male first-grade high school students living in the eastern Isfahan in Iran, as an endemic region of leishmaniasis in Isfahan province, from January 2021 to May 2021. Multistage Random sampling was performed so that two cities (Mohammadabad and Hosseinabad with similar demographic variables and high incidence of CL) were first selected from cities located in Eastern Isfahan. Then, one 


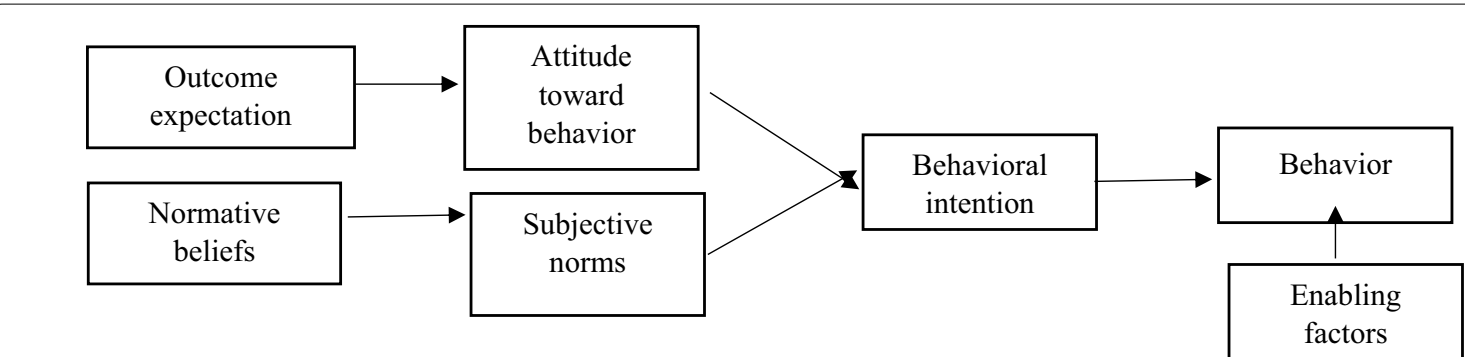

Schematic of BASNEF model

Fig. 1 Schematic of BASNEF model

of these two cities was randomly chosen as the city from which the students in the intervention group were drawn out and the other city was regarded as the city whose students were supposed to be included in the control group. After that, one school was randomly selected from each city and according to the list of students, 42 students were systematically chosen from the students of each school to be assigned to each group. The number of samples was calculated to be at least 70 by considering a $95 \%$ confidence level, $80 \%$ test power, and $10 \%$ probability of attrition [29].

The inclusion criteria were as follows: Studying at the first-grade high school, and the consent of students or their parents to participate in the study.

Individuals, who did not complete the questionnaires and educational sessions were excluded from the study.

\section{Data gathering tool}

In this study, to collect data, the BASNEF model questionnaire, which was designed and validated by Ghodsi et al. [29] was used. The questionnaire included the following sections:

1. Demographic characteristics including the parents' education levels, the students' or their family members' status of being/not being infected with CL, the status of place of residence.

2. Knowledge items included four questions, which were designed as correct- incorrect and I do not know. The correct, I do not know, and incorrect options were scored 2, 1, and 0, respectively. Example: $C L$ is transmitted by sandflies.

3. The section about the BASNEF model constructs, which included 32 questions, was as follows:

Six attitude-related items, including behavioral beliefs and outcome evaluation. For example: If I pursue CL prevention behaviors, I will not get it.
Eight subjective norms-related items, including normative beliefs and motivation to comply.

For example: How much do you try to do your activities based on your family, friends, classmates, health workers, teachers, and educators expectation?

Eight behavioral intention-related items. Example: I intend to use an insect repellent pen to protect myself from mosquito bites.

Five enabling factors-related items. Example: Existence of financial resources to buy wire net, insect repellent pen, insecticides, etc.

Five behavior-related items. Example: in the last three months, to what extent have you used insecticides to eliminate mosquitoes at home?

To answer the above items, the five-point Likert scale was used which were scored from 0 to 4 . In each construct, a higher score indicated a better status. For the ease of comparison, in different sections of the questionnaire, all scores were reported out of 100 .

AGFI $=0.9$ and RMESA $=0.04$ were obtained in the construct validity. The reliability of the questionnaire was confirmed using internal consistency $(\alpha=0.864)$ [29].

\section{Educational intervention}

The educational content was set by reviewing the existing literature (guidebooks, the prevention of Cutaneous Leishmaniasis by the Zoonosis Center for Disease Control of the Ministry of Health). In the intervention group, the educational intervention was conducted in three 60-min sessions in the form of lectures, group discussions, brainstorming, questions and answers, and practical demonstrations.

The first session included various educational methods such as lectures, showing photos and videos, and questions and answers on the agent, reservoir, and vectors of $\mathrm{CL}$, gathering and resting places, and time of sandfly bites. Then, the role of body cover, using pen repellent, and insecticide spray on the prevention of bites was explained. 
The second session discussed the most important common beliefs about CL in the region as well as their right and wrong nature, the way of changing misconceptions in families, and the importance of CL prevention behaviors among students.

In the third session, students became familiar with the facilitators and barriers to CL prevention behaviors and practiced overcoming strategies, appropriate window nets and mosquito netting were also directly shown to the students and their effective role in the prevention of bites was explained, and they practically learnt how to use insect repellent pen.

Table 1 summarizes the presented training based on the BASNEF model constructs.

To attract the students' social support, a training session was designed for parents and teachers on CL prevention behavior and its importance. In this sessions, in addition to providing necessary training (e.g. about the reservoir and vector of CL, time of mosquito bites, the resting place of mosquito, the correct way of using insect repellent pen, the impact of insecticide spray, and features of appropriate mosquito netting), parents and teachers were recommended to appropriately support students to adopt CL prevention behaviors.

The questionnaires were completed by students of the two groups before the training sessions and two months after the end of the sessions.

\section{Data analysis}

The completed questionnaires before and after the intervention were inserted into SPSS (Ver. 26).

To compare demographic variables between the two groups, the Chi-square and Independent t-test were used. Before the intervention, the mean scores of knowledge and constructs of the BASNEF model between the two groups were compared through the Independent $\mathrm{t}$-test, while after the intervention, scores of knowledge and constructs of the BASNEF model between the two groups were compared by using analysis of covariance(ANCOVA). The Paired t-test was also employed to compare mean scores of knowledge and constructs of the BASNEF model in each group before and after the intervention.

\section{Results}

In the present study, the mean age of students in the intervention and control groups was $14.3 \pm 1.03$ and $14.1 \pm 0.8$ years, respectively. The independent $\mathrm{t}$-test indicated that there was not any significant difference between the two groups in terms of the mean age $(\mathrm{P}=0.28)$ and the number of family members $(\mathrm{P}=0.34)$.

The Chi-square test, on the other hand, indicated that there was not any significant difference between the two groups in terms of the frequency distribution of $C L$ status $(P=0.20)$, the status of $C L$ in the family

Table 1 Summary of education based on the BASNEF model constructs

\begin{tabular}{|c|c|c|c|}
\hline BASNEF model constructs & Cognitive-behavioral goals & Learning domain & Educational technique \\
\hline Knowledge & $\begin{array}{l}\text { Learning about the reservoir and vectors } \\
\text { of the disease, resting place, and time of } \\
\text { mosquito bites, the role of body cover, insect } \\
\text { repellent pen, insecticide spray, and charac- } \\
\text { teristics of window net and suitable mosquito } \\
\text { netting for preventing CL }\end{array}$ & Cognitive & Lecture, question and answer, PowerPoint \\
\hline Attitude & $\begin{array}{l}\text { Discussing the most important common } \\
\text { beliefs, their nature of being right or wrong } \\
\text { common beliefs, the way of changing } \\
\text { misconceptions, and the importance of } \mathrm{CL} \\
\text { prevention behaviors to prevent infection }\end{array}$ & Affective & Questions and answer, group discussion \\
\hline Subjective norms & $\begin{array}{l}\text { Familiarization of parents and teachers with } \\
\mathrm{CL} \text { and prevention methods to continuously } \\
\text { transmit this information to students and } \\
\text { improve social support from teachers and } \\
\text { students' parents }\end{array}$ & Cognitive-affective & Questions and answer (group discussion \\
\hline Enabling factors & $\begin{array}{l}\text { Facilitators and barriers to performing preven- } \\
\text { tive behaviors, increasing the skill of using } \\
\text { a repellent pen and spray, and introducing } \\
\text { appropriate nets and mosquito netting, and } \\
\text { solutions to overcome barriers to CL preven- } \\
\text { tion behaviors }\end{array}$ & Cognitive-psychomotor & Lecture, practical demonstration, role-playing \\
\hline
\end{tabular}


$(\mathrm{P}=0.65)$, as well as the frequency distribution of the residence place $(P=0.26)$, and the residence status $(P=0.47)$. Also, the Mann-Whitney test showed that there was not any significant difference between the two groups in terms of students' education grade $(\mathrm{P}=0.25)$, fathers' education level $(\mathrm{P}=0.20)$, and mothers' education level $(\mathrm{P}=0.08)$ (Table 2$)$.

Moreover, the ANCOVA test revealed that after the educational intervention, the mean scores of knowledge $(\mathrm{P}<0.001)$, attitude $(\mathrm{P}=0.02)$, behavioral intention $(\mathrm{P}<0.001)$, behavior $(\mathrm{P}=0.02)$, and subjective norms $(\mathrm{P}=0.04)$ were significantly higher in the intervention group than the control group, but there was not any significant difference between mean scores of enabling factors of the two groups $(\mathrm{P}=0.93)$. (Table 3 ).

The paired $\mathrm{t}$-test indicated that in the intervention group, the mean scores of knowledge $(\mathrm{P}<0.001)$, attitude $(\mathrm{P}=0.002)$, behavioral intention $(\mathrm{P}<0.001)$, behavior $(\mathrm{P}=0.01)$, and subjective norms $(\mathrm{P}=0.04)$ were significantly higher after the intervention compared with before the intervention, but the mean scores of enabling factors after the intervention were not significantly different from those obtained before the intervention ( $\mathrm{P}=0.53)$. The same test showed that in the control group, the mean scores of BASNEF model constructs after the intervention were not significantly different from those obtained after the educational intervention $(\mathrm{P}>0.05)$ (Table 4$)$.

\section{Discussion}

The present study aimed to determine the impact of educational interventions on the improvement of CL prevention behaviors among the male first-grade high school students in east Isfahan (an endemic region of CL).

Table 2 Comparison of demographic characteristics between experimental and control groups

\begin{tabular}{|c|c|c|c|c|c|}
\hline \multirow[t]{2}{*}{ Variable } & \multicolumn{2}{|c|}{ Experimental group } & \multicolumn{2}{|c|}{ Control group } & \multirow[t]{2}{*}{ P-value } \\
\hline & No & Percentage & No & Percentage & \\
\hline \multicolumn{6}{|l|}{ CL status in students } \\
\hline Currently suffering from CL & 1 & 2.5 & 0 & 0 & \multirow[t]{3}{*}{0.20} \\
\hline $\begin{array}{l}\text { Previously infected with cutaneous leish- } \\
\text { maniasis }\end{array}$ & 13 & 32.5 & 8 & 20 & \\
\hline No history of CL & 26 & 65 & 32 & 80 & \\
\hline \multicolumn{6}{|l|}{ CL status in the family } \\
\hline Currently suffering from CL & 3 & 7.5 & 2 & 5 & \multirow[t]{3}{*}{0.65} \\
\hline Previously infected with $C L$ & 18 & 45 & 15 & 37.5 & \\
\hline No history of CL & 19 & 47.5 & 23 & 57.5 & \\
\hline \multicolumn{6}{|l|}{ Place of residence } \\
\hline Suburbs & 26 & 65 & 21 & 52.5 & \multirow[t]{2}{*}{0.26} \\
\hline Downtown & 14 & 35 & 19 & 47.5 & \\
\hline \multicolumn{6}{|l|}{ Residence place status } \\
\hline Newly constructed & 26 & 65 & 29 & 72.5 & \multirow[t]{2}{*}{0.47} \\
\hline Old & 14 & 35 & 11 & 27.5 & \\
\hline \multicolumn{6}{|l|}{ Educational grade } \\
\hline Grade 7 & 10 & 25 & 12 & 30 & \multirow[t]{3}{*}{0.25} \\
\hline Grade 8 & 12 & 30 & 16 & 40 & \\
\hline Grade 9 & 18 & 45 & 12 & 30 & \\
\hline \multicolumn{6}{|l|}{ Fathers' educational level } \\
\hline Illiterate & 4 & 10 & 7 & 17.5 & \multirow[t]{4}{*}{0.20} \\
\hline Primary and secondary school & 19 & 47.5 & 22 & 55 & \\
\hline High school diploma & 13 & 32.5 & 6 & 15 & \\
\hline Academic & 4 & 10 & 5 & 12.5 & \\
\hline \multicolumn{6}{|l|}{ Mothers' educational level } \\
\hline Illiterate & 4 & 10 & 8 & 20 & \multirow[t]{4}{*}{0.08} \\
\hline Primary and secondary school & 19 & 47.5 & 22 & 55 & \\
\hline High school diploma & 11 & 27.5 & 6 & 15 & \\
\hline Academic & 6 & 15 & 4 & 10 & \\
\hline
\end{tabular}


Table 3 The Comparison of mean scores of BASNEF model constructs between the intervention and control groups before and two months after educational intervention (Between-group comparison)

\begin{tabular}{|c|c|c|c|c|}
\hline Variable & & $\begin{array}{l}\text { Intervention group } \\
\text { Mean (SD) }\end{array}$ & $\begin{array}{l}\text { Control group } \\
\text { Mean (SD) }\end{array}$ & P-value \\
\hline \multirow[t]{2}{*}{ Knowledge } & Before intervention & $61.9(20.4)$ & $63.6(21.7)$ & $0.71^{*}$ \\
\hline & After intervention & $86.2(13.8)$ & $62.4(20.4)$ & $<0.001^{* *}$ \\
\hline \multirow[t]{2}{*}{ Attitude } & Before intervention & $72.8(18.9)$ & $73.4(19.6)$ & $0.90^{*}$ \\
\hline & After intervention & $81.6(15.6)$ & $72.9(18.5)$ & $0.02^{* *}$ \\
\hline \multirow[t]{2}{*}{ Behavioral intention } & Before intervention & $67.5(19.3)$ & $70.6(15.9)$ & $0.45^{*}$ \\
\hline & After intervention & $82.7(10.9)$ & $70.9(14.4)$ & $<0.001^{* *}$ \\
\hline \multirow[t]{2}{*}{ Behavior } & Before intervention & $54.1(25.6)$ & $56.8(21.04)$ & $0.61^{*}$ \\
\hline & After intervention & $66.2(18.5)$ & $55.3(23.6)$ & $0.02^{* *}$ \\
\hline \multirow[t]{2}{*}{ Subjective norms } & Before intervention & $71.8(19.1)$ & $73.8(18.1)$ & $0.63^{*}$ \\
\hline & After intervention & $77.4(15.3)$ & $70.8(17.1)$ & $0.04^{* *}$ \\
\hline \multirow[t]{2}{*}{ Enabling factors } & Before intervention & $68.4(19.8)$ & $69.6(20.3)$ & $0.79^{*}$ \\
\hline & After intervention & $70.4(13.3)$ & $69.7(16.2)$ & $0.93^{* *}$ \\
\hline
\end{tabular}

*Independent T-test

** ANCOVA T-test

Table 4 Comparison of mean scores of the BASNEF model constructs in each of the intervention and control groups before and two months after the educational intervention (Within-group comparison)

\begin{tabular}{|c|c|c|c|c|}
\hline Variable & & $\begin{array}{l}\text { Before intervention Mean } \\
\text { (SD) }\end{array}$ & After intervention Mean (SD) & P-value* \\
\hline \multirow[t]{2}{*}{ Knowledge } & Intervention group & $61.9(20.4)$ & $86.2(13.8)$ & $<0.001$ \\
\hline & Control group & $63.6(21.7)$ & $62.4(20.4)$ & 0.77 \\
\hline \multirow[t]{2}{*}{ Attitude } & Intervention group & $72.8(18.9)$ & $81.6(15.6)$ & 0.002 \\
\hline & Control group & $73.4(19.6)$ & $72.9(18.5)$ & 0.93 \\
\hline \multirow[t]{2}{*}{ Behavioral intention } & Intervention group & $67.5(19.3)$ & $82.7(10.9)$ & $<0.001$ \\
\hline & Control group & $70.6(15.9)$ & $70.9(14.4)$ & 0.92 \\
\hline \multirow[t]{2}{*}{ Behavior } & Intervention group & $54.1(25.6)$ & $66.2(18.5)$ & 0.01 \\
\hline & Control group & $56.8(21.04)$ & $55.3(23.6)$ & 0.75 \\
\hline \multirow[t]{2}{*}{ Subjective norms } & Intervention group & $71.8(19.1)$ & $77.4(15.3)$ & 0.04 \\
\hline & Control group & $73.8(18.1)$ & $70.8(17.1)$ & 0.36 \\
\hline \multirow[t]{2}{*}{ Enabling factors } & Intervention group & $68.4(19.8)$ & $70.4(13.3)$ & 0.53 \\
\hline & Control group & $69.6(20.3)$ & $69.7(16.2)$ & 0.90 \\
\hline
\end{tabular}

*Paired T-test

In the study, the intervention and control groups were homogeneous in terms of demographic characteristics. The mean scores of knowledge and constructs of the BASNEF model were not significantly different between the intervention and control groups before the educational intervention, indicating a minimum effect of confounding variables on the research results.

The results further indicated a significant increase in the mean knowledge score of the intervention group after intervention, while there was not any significant change in the control group, indicating the effect of education on raising students' knowledge about CL.
The necessary and correct information about the disease is the most basic step towards appropriate behavior. Some studies similarly suggest that educational intervention based on the BASNEF model is more effective in raising knowledge than classic education [30, 31].

The reason for the intervention group's higher attitude mean score after the intervention was student's participation in the educational sessions, the management of the educational sessions based on workshop method, and learning through problem solving, which not only did not inject the students with educational content, but also allowed them to express their ideas and beliefs. In 
fact, expressing idea and seeing other people's reactions is a powerful way to change attitudes confirmed in other studies [32].

In studies by Shabidar et al. and Azideh maab et al., which were both on the effect of interventions on attitude change, the educational intervention did not significantly change the attitude scores of the participants [33, 34]. The difference in the effect of education on attitudes in different studies might be rooted in the fact that compared with knowledge, attitude and behavior are often affected by a set of multiple environmental and social factors; hence, education and information alone cannot correct them. Therefore, increasing knowledge alone cannot improve attitude.

Based on the results of the present study, subjective norms, such as parents, friends, classmates, and teachers play important roles in providing appropriate social support for students. Therefore, in addition to providing students with educational interventions, influential individuals in the students' life should be identified and become directly and indirectly involved in educational interventions because important others (subjective norms) could be very effective in behavioral changes [35, 36].

In the present study, the mean scores of the behavioral intention of the students in the intervention group increased after educational intervention. Behavioral intention is an index showing a person's readiness to perform a particular behavior and is an immediate predictor of behavior. Intentions contain motivational factors that are resulted from attitudes and subjective norms; hence, they can lead to behavior. On the other hand, a positive attitude towards behavior alone cannot guarantee the performance of the behavior, but according to theories and models, attitudes affect the performance of behavior by affecting the behavioral intention. The subjective norms, or people who are important to a person, can also help the person in the behavioral intention [37].

An effective factor in performing CL prevention behaviors is the availability of a suitable insect repellent pen, spray, and mosquito netting. Given that these items are relatively expensive and most students were from either low- or medium-income families, they couldn't afford to buy these items despite having the appropriate knowledge and attitude towards the provision of these preventive items. Lack of supply of these items for free during the education by the local health center (some of these items had been distributed for free leading to expectations in the residents) was a reason for the significant increase in scores of enabling factors in the intervention group after the intervention.

Pardo's et al. study indicated that families with better economic status and higher income use more preventive means than other people; thus, the incidence of the disease was lower among them [38].

In studies by Sharifirad [39] and Mohebi [40], easy access and cost were the most important enabling factors. In contrast with the present study, in studies by Hazavei et al. [41], Arefi et al. [32], which were conducted based on the BASNEF model, the increase in mean scores of enabling factors was significant after the educational intervention.

The results indicated that the students' behavior mean scores significantly increased in the intervention group after the educational intervention, indicating the impact of the intervention based on the BASNEF model.

\section{Conclusion}

Educational intervention based on the BASNEF model increased the knowledge and skills necessary for CL prevention behaviors. However, some barriers cannot be removed by educational interventions alone. These barriers include lack of money to buy the necessary equipment, the presence of rubble and construction debris in residential areas, and the low level of environmental health, etc.

Asking for other organizations' help (municipalities, environment, housing, etc.) and charitable groups and non-governmental organizations, and attracting intersectoral collaboration are main solutions to solve the problem of $\mathrm{CL}$ in endemic regions. Therefore, it seems that a very suitable solution is to attract comprehensive support that should be provided by the national health care system to attract the participation of various groups and organizations to improve CL prevention behaviors among people living in endemic regions.

The use of a model base intervention to promote preventive behaviors from $\mathrm{CL}$ was among the strengths of the research; nonetheless, holding face-to-face educational sessions was confronted with limitation due to COVID-19 outbreak.

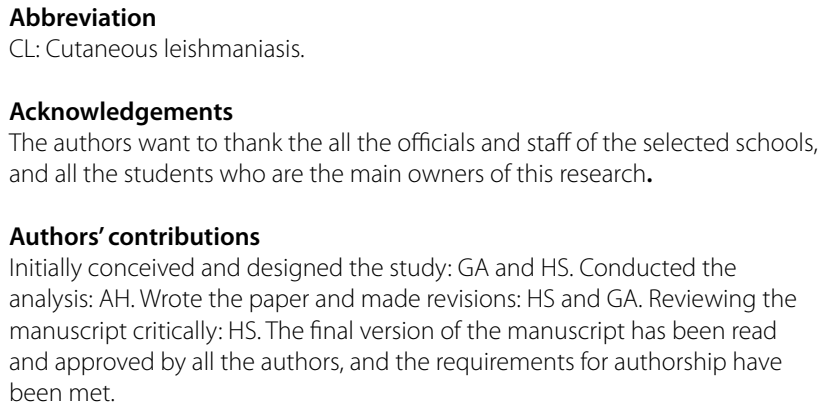




\section{Funding}

The Isfahan University of Medical Sciences funded this study. However, this grant did not cover the most sections of this study.

\section{Availability of data and materials}

The data that support the findings of this study are available from Deputy of research of Isfahan University of Medical Sciences but restrictions apply to the availability of these data, which were used under license for the current study, and so are not publicly available. Data are however available from the authors upon reasonable request and with permission of Isfahan University of Medical Sciences.

\section{Declarations}

\section{Ethics approval and consent to participate}

The students received complete information about the research purposes. Informed consent was obtained from students and parent of all participants who were under 16 years old. All methods were carried out in accordance with relevant guidelines and regulations. The clinical trial was registered on the website of the Iranian Registry of Clinical Trials (IRCT20201024049131N1) and received a code of ethics (IR.MUI.RESEARCH.REC.1399.463) from the National Ethics Committee in the Iranian Biomedical Research (file:///C:/Users/ DRshahnazi1/Downloads/jmy8akqieji3b8yl\%20(1).pdf.

\section{Consent for publication}

Not applicable.

\section{Competing interests}

The authors declare that they have no competing interests.

\section{Author details}

${ }^{1}$ School of Health, Isfahan University of Medical Sciences, Isfahan, Iran. ${ }^{2}$ Department of Health Education and Health Promotion, School of Health, Isfahan University of Medical Sciences, Isfahan, Iran. ${ }^{3}$ Department of Epidemiology and Biostatistics, Isfahan University of Medical Sciences, Isfahan, Iran.

Received: 10 August 2021 Accepted: 15 November 2021 Published online: 17 November 2021

\section{References}

1. Karunaweera ND, Ferreira MU. Leishmaniasis: current challenges and prospects for elimination with special focus on the South Asian region. Parasitology. 2018;145(4):425-9.

2. Alidosti M, Heidari Z, Shahnazi H, Zamani-Alavijeh F. Behaviors and perceptions related to cutaneous leishmaniasis in endemic areas of the world: a review. Acta Trop. 2021;223:106090.

3. Alharazi TH, Haouas N, Al-Mekhlafi HM. Knowledge and attitude towards cutaneous leishmaniasis among rural endemic communities in Shara'b district, Taiz, southwestern Yemen. BMC Infect Dis. 2021;21(1):269.

4. Al-Harbi AS, Hakami AM, Mohammed A-HY, Allah A-MKD, Alfaris AM, Alghamdi AJ, et al. Knowledge, attitude and practice regarding the cutaneous leishmaniasis among infected patients and their families in Al-Madinah Al-Munawarah. GSCARR. 2021;6(1):76-89.

5. Al-Obaidi MJ, Ali HB. Evaluation of the surveillance and epidemiological aspects of cutaneous leishmaniasis in Babylon Province, Iraq. Iraqi J Sci. 2021;62(3):793-800.

6. Du R, Hotez PJ, Al-Salem WS, Acosta-Serrano A. Old world cutaneous leishmaniasis and refugee crises in the Middle East and North Africa. Plos Negl Trop Dis pntd. 2016;10(5):e0004545.

7. Shirzadi MR, Esfahania SB, Mohebalia M, Ershadia MR, Gharachorlo F, Razavia MR, et al. Epidemiological status of leishmaniasis in the Islamic Republic of Iran 1983-2012. East Mediterr Health J. 2015;21(10):736-42.

8. Khan A, Khan K, Biradar G, Khan M. Treatment of cutaneous leishmaniasis with photodynamic therapy: the first case report from Khyber Pakhthunkhwa (KPK), Swat Pakistan. J Pak Assoc Dermatol. 2021;31(1):120-4.
9. Diogo TC, de Souza DC, de Castro VN, Geiger SM, Barbosa DS. Identification of priority areas for surveillance of cutaneous leishmaniasis using spatial analysis approaches in Southeastern Brazil. BMC Infect Dis. 2019;19:318.

10. Mandal R, Kesari S, Kumar V, Das P. Trends in spatio-temporal dynamics of visceral leishmaniasis cases in a highly-endemic focus of Bihar, India: an investigation based on GIS tools. Parasit Vectors. 2018;11(1):220.

11. Bigdeli S, Maraghi E, Sharififard M, Jahanifard E. HanafiBojd AA (2020) Influence of climatic factors on probability of presence and geographical distribution of Phlebotomus papatasi, main vector of zoonotic cutaneous leishmaniasis, in selected counties of Khuzestan Province. J Neyshabur Univ Med Sci. 2018:8(4):101-11.

12. Liu Z, Kundu R, Damena S, Biter AB, Nyon MP, Chen W-H, et al. A scalable and reproducible manufacturing process for Phlebotomus papatasi salivary protein PpSP15, a vaccine candidate for leishmaniasis. Protein Express Purif. 2021;177:1-9.

13. Yaghoobi-Ershadi MR. Control of phlebotomine sand flies in Iran. J Arthropod-Borne Dis. 2016;10(4):429-44.

14. Karimi A, Hanafi-Bojd AA, Yaghoobi-Ershadi MR, Akhavan AA, Ghezelbash Z. Spatial and temporal distributions of phlebotomine sand flies (Diptera: Psychodidae), vectors of leishmaniasis, in Iran. Acta Trop. 2014;132:131-9.

15. Abuzaid AA, Abdoon AM, Aldahan MA, Alzahrani AG, Alhakeem RF, Asiri AM, et al. Cutaneous leishmaniasis in Saudi Arabia: a comprehensive overview. Vector Borne Zoonotic Dis VBZ. 2017;17(10):673-84.

16. Pagheh AS, Fakhar M, Mesgarian F, Rahimi-esboei B, Badiee F. Incidence trend of rural cutaneous leishmaniasis in Gonbad-e-Qabus City (Golestan Iran), during 2009-2012. J Mazand Univ Med Sci. 2013;23(104):27-33.

17. Abedi-Astaneh F, Hajjaran $\mathrm{H}$, Yaghoobi-Ershadi MR, Hanafi-Bojd AA, Mohebali M, Shirzadi MR, et al. Risk mapping and situational analysis of cutaneous leishmaniasis in an endemic area of central Iran: a GIS-based survey. PLoS ONE. 2016;11(8):e0161317.

18. Chelbi I, Mathlouthi O, Zhioua S, Fares W, Boujaama A, Cherni S, Barhoumi W, Dachraoui K, Derbali M, Abbass M, Zhioua E. The impact of illegal waste sites on the transmission of zoonotic cutaneous leishmaniasis in Central Tunisia. Int J Environ Res Public Health. 2021;18(1):66.

19. Saghafipour A, Mirheydari M, Abolkheirian S, Arsang JS. Effectiveness of educational intervention based on BASNEF model to promote preventive behaviors of cutaneous leishmaniasis among students in Qom Province. J Health. 2017;8:170-81.

20. Jeihooni AK, Harsini PA, Kashfi SM, Rakhshani T. Effect of educational intervention based on the PRECEDE-PROCEED model on preventive behaviors of cutaneous leishmaniasis among housewives. Cad Saude Publica. 2019;35(7):e00158818.

21. Ghodsi M, Maheri M, Joveini H, Rakhshani MH, Mehri A. Designing and evaluating educational intervention to improve preventive behavior against cutaneous leishmaniasis in endemic areas in Iran. Osong Public Health Res Perspect. 2019;10(4):253-62.

22. Saghafipour A, Nejati J, Mozaffari E, Rezaei F, Gharlipour Z, Mirheydari M. The effectiveness of education based on BASNEF model on promoting preventive behavior of cutaneous leishmaniasis in students. Int J Pediatr. 2017:5(6):5125-36.

23. Heshmati H, Charkazi A, Hazavehei SMM, Rahaei Z, Dehnadi A. Factors related to cutaneous leishmaniasis preventive behaviors on the basis of BASNEF model in residents of endemic area in Yazd Iran. Res; Health Syst. 2012;7(6):1.

24. Irum S, Aftab M, Khan A, Naz S, Simsek S, Habib A, et al. Cutaneous leishmaniasis (CL): a cross-sectional community based survey on knowledge, attitude and practices in a highly endemic area of Waziristan (KPK Province), Pakistan. Acta Trop. 2021;213:105746.

25. Saberi S, Zamani AR, Moatamedi N, Nilforoushzadeh MA, Jaffary F, Rahimi $\mathrm{E}$, et al. Evaluation of students' knowledge, attitude and practice in relation to preventive strategies against leishmaniasis in the hyperendemic region of Shahid Babaie airbase. J Isfahan Med School. 2012;29:2962-70.

26. Tesfay K, Mardu F, Berhe B, Negash H, Legese H, Adhanom G, et al. Household knowledge, practice and treatment seeking behaviors towards cutaneous leishmaniasis in the endemic rural communities of Gantaafeshum district, Tigrai, northern Ethiopia, 2019: a cross-sectional study. Trop Dis Travel Med Vaccines. 2021;7(1):19.

27. Amahmid O, Guamri YE, Zenjari K, Bouhout S, Moh MA, Boraam F, et al. Epidemiological features of cutaneous leishmaniasis in diagnosed 
patients from an endemic area (central Morocco). J Parasit Dis. 2021;45(3):762-8.

28. Haghani S, Shahnazi H, Hassanzadeh A. Effects of tailored health education program on overweight elementary school students' obesityrelated lifestyle: a school-based interventional study. Oman Med J. 2017;32(2):140-7.

29. Ghodsi M, Maheri M, Joveini H, Rakhshani MH. Development and psychometric of assessment tool of students' preventive behaviors of cutaneous leishmaniosis based on BASNEF model. Neyshabur Univ Med Sci. 2017;5(2):32-46.

30. Rastgoo F, Vasli P, Rohani C, Amini A. Predictors of osteoporosis preventive behaviors among adolescent: a cross-sectional study. Pediatr Endocrinol Diab Metab. 2021;27:43925.

31. Esteki-Ghashghaei F, Saadatnia M, Khorvash F, Shahnazi H. The Effect of home base physical activity program based on the BASNEF model on motor recovery in patients with stroke. Home Health Care Serv Q. 2020;39(3):154-67.

32. Arefi Z, Hekamatpou D, Orouji MA, Shaahmadi Z, Khushemehri G, Shaahmadi $F$. The effect of educational intervention based on BASNEF model on decreasing the cesarean section rate among pregnant women in Khomain Country. J Family Reprod Health. 2015;9(3):101-5.

33. Shabbidar S, Fathi B. Effects of nutrition education on knowledge and attitudes of type 2 diabetic patients. J Birjand Univ Med Sci. 2007;14(1):9-15.

34. Azide Mab W, Talib RA, Zabidi AM. Changes in nutrition knowledge and attitude scores in 8 years old school children after receiving nutrition education: a preliminary finding. Nutr Goals Asia-Vision. 2020;13:23-7.

35. Gholamian B, Shahnazi H, Hassanzadeh A. The effect of educational intervention based on BASNEF model for reducing internet addiction among female students: a quasi-experimental study. Italy J Pediatr. 2019;45(1):164.

36. Khani Jeihooni A, Amirkhani M, Rakhshani T, Hasirini PA, Jormand H. Factors associated with suicidal ideation in drug addicts based on the theory of planned behavior. BMC Psychiatry. 2021;21(1):372

37. Hajivandi L, Noroozi M, Mostafavi F, Ekramzadeh M. Assessing the impact of an educational intervention program based on the theory of planned behavior on the nutritional behaviors of adolescents and young adults with PCOS in Iran: a field trial study. BMC Pediatr. 2021;21(1):316.

38. Pardo RH, Carvajal A, Ferro C, Davies CR. Effect of knowledge and economic status on sand fly control activities by householders at risk of cutaneous leishmaniasis in the subandean region of Huila department, Colombia. Biomedica. 2006;26(1):167-79.

39. Sharifirad G, Kamran A. Effective factors on smoking behavior based on BASNEF model in students dormitory at Isfahan University of Medical Sciences. Zahedan J Res Med Sci. 2008;11(4):275-9.

40. Mohebi S, Shahsiah M, Matlabi M. The study of factors influencing smoking among male University Students in Kermanshah. Knowl Health. 2010;5(23):5-11.

41. Hazavehei SMM, Heshmati H, Hasanzadeh A, Hosseini SH, Ghanbari MR, Behravesh O. Adjustment and completion of BASNEF model to provide a new model for educating large populations in relation to cutaneous leishmaniasis. J Zoonoses. 2014;1 (1):28-39.

\section{Publisher's Note}

Springer Nature remains neutral with regard to jurisdictional claims in published maps and institutional affiliations.
Ready to submit your research? Choose BMC and benefit from:

- fast, convenient online submission

- thorough peer review by experienced researchers in your field

- rapid publication on acceptance

- support for research data, including large and complex data types

- gold Open Access which fosters wider collaboration and increased citations

- maximum visibility for your research: over $100 \mathrm{M}$ website views per year

At BMC, research is always in progress.

Learn more biomedcentral.com/submissions 